\title{
Analisis Makna Kata Ageru, Kureru, Morau Dalam Kalimat Bahasa Jepang
}

\author{
Igat Meliana, Dhea Savitri
}

Program Studi Bahasa Jepang, STBA Cipto Hadi Pranoto, Indonesia e-mail: igatmeliana240@gmail.com

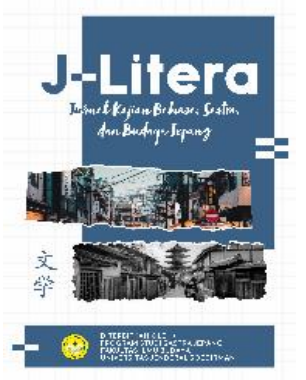

\section{Abstract}

Ageru (あげる) and Kureru (くれる) Verbs mean "to give", while Morau (もらう) verb means "to receive". The reaserch problem is the meaning of Ageru (あげる), Kureru ( $く れ る$ ), Morau (もらう) verbs that used on depending on who gives and who receives whether the closest person to the speaker (relative) or outside the scope of the speaker (other people). The method used is descriptive literature. The purpose of this study was to determine the meaning of the words Ageru, Kureru, Morau, the use of Ageru, Kureru, Morau, and the differences between Ageru, Kureru and Morau. The results of the analysis concluded that: 1 . Ageru (あげる) which means "to give" where the first person is the speaker, to a scope far from the speaker. 2. Kureru $(<れ る)$ which means "to give" where the second person gives to the first person (speaker), the flow of the object / gift approaches from outsiders to the speaker or relatives of the speaker. 3. Morau (もらう) which means "to accept" is general in nature anyone can use it as an expression of acceptance of something from someone.
\end{abstract}

Keywords:

Meaning; Ageru; Kureru; Morau

Article Info:

First received:

25 March 2021

Available online:

28 May 2021

\section{PENDAHULUAN}

Pembelajar bahasa Jepang sering kesulitan dalam memaknai kata Ageru (あげる), Kureru (くれる) dan Morau (もらう), contohnya :

1). Ageru (あげる) 日本はインドネシアに援助 をあげました。[Sutedi, 2007] (Nihon wa Indonesia ni enjo o agemashita. Jepang memberi bantuan kepada Indonesia);

2). Kureru (くれる) 日本はインドネシアに援助 をくれました。[Sutedi, 2007] (Nihon wa Indonesia ni enjo o kuremashita. Jepang memberi bantuan kepada Indonesia;

3). Morau (もらう) インドネシアは日本から援 助をもらいました。[Sutedi, 2007] Indonesia wa Nihon kara enjo o moraimashita. Indonesia menerima bantuan dari Jepang.

Kosakata tersebut kata ageru (あげる) dan kureru (くれる) sama-sama memiliki arti "memberi" sedangkan kata morau (もらう) memiliki arti "menerima", hal tersebut yang mendasari pembelajar asing yang mempelajari bahasa Jepang kesulitan dalam memaknai kata tersebut.
Kata "memberi" yang seperti apa yang akan digunakan saat ingin berbicara atau membuat kalimat menggunakan ageru (あげる) dan kureru (くれる); dan perbedaannya seperti apa kata ageru (あげる) dan kureru (くれる) dan morau ( もらう) itu, dilihat dari sudut pandang siapa dan kedudukan yang seperti apa saat menggunakan kata ageru (あげる), kureru (くれる) dan morau ( もらう).

Kata kerja ageru (あげる) termasuk kata kerja golongan kedua. Dalam membuat kalimat, jarang sekali hanya menggunakan kalimat ageru (あげる) dalam bentuk kamus jisho-kei (辞書形), biasanya diperhalus menggunakan bentuk masukei (ます形 ) sebagai rasa hormat pembicara terhadap lawan bicaranya, dan menggunakan bentuk lampau -mashita (ました) sebagai kata keterangan bahwa aksi/kegiatan tersebut sudah terjadi (lampau) [Kurniawan, 2014].

Penggunaan kata kerja ageru (あげる), kata kerja ageru (あげる) biasanya digunakan oleh orang yang kedudukan/derajatnya sama atau lebih rendah dari pembicara. Contohnya seperti berbicara dengan teman sebaya, adik kelas dan 
lain sebagainya. Pola kalimat kata kerja ageru ( あげる) “memberi” adalah :

〜は〜に〜をあげる。

A wa B ni C wo ageru:

A memberikan C (objek) kepada B.

(Lusiana dkk, 2009)

\section{Analisis Kalimat Ageru dan Kureru}

Terdapat delapan contoh kalimat yang diteliti dalam penelitian ini. Data penelitian diambil dari berbagai buku yang dipakai di Sekolah Tinggi Bahasa Asing Cipto Hadi Pranoto, yaitu:

1. 田中先生は私に辞書をくれました (Tanaka sensei wa watashi ni jisho wo kuremashita) yang artinya "Pak guru Tananaka memberi kamus kepada saya", kata kerja kureru (くれる) dalam bentuk kamus jisho-kei (辞書形) yang diubah kedalam bentuk sopan lampau mashita (ま した) menjadi kuremashita (くれました) yang artinya pak guru Tanaka "telah memberikan" suatu benda berupa (kamus) kepada saya watashi (私) sebagai pembicara yang tentu saja sangat menghormati kedudukan pak guru Tanaka sebagai guru/orang yang derajatnya lebih tinggi dari pada saya watashi (私) sebagai muridnya. Kata kerja kureru (くれる) tidak bisa menjadikan orang pertama sebagai pelaku/si pemberi benda atau sebuah kebaikan. Dalam contoh kalimat di atas maknanya adalah, pak guru Tanaka dalam konteks ini bukan bagian dari keluarga pembicara memberikan kamus kepada pembicara yang artinya alur perpindahan benda tersebut, dari orang lain kepada penerima yaitu watashi (私) "saya" sebagai pembicara sebagai pembicara.

2. 山田さんはあなたに何をくれましたか (Yamada san wa anata ni nani wo kuremashita ka) yang artinya "Pak Yamada telah memberi apa kepada anda?".

Kata kerja kureru (くれる) dalam bentuk kamus jisho-kei (辞書形) yang diubah kedalam bentuk sopan lampau mashita (ま
した) menjadi kuremashita (くれました). Ditambah dengan kalimat tanya $k a$ (か) yang berarti kalimat ini adalah sebuah kalimat pertanyaan yang ditanyakan oleh si pembicara terhadap lawan bicaranya. Sehingga kalimat ini dapat diartikan bahwa pak Yamada "telah memberi apa?" kepada anda.

Kalimat ini diucapkan dari sudut pandang pembicara yang ingin mengetahui apa yang telah diberikan pak Yamada kepada anda. Selain itu, kalimat ini juga menggunakan kalimat bentuk sopan lampau mashita (まし た) sebagai rasa hormat kepada pembicara.

Makna dari kalimat ini adalah, pembicara mengganggap anata (あなた) "anda" adalah bagian dari keluarga atau masih dalam ruang lingkup pembicara, oleh sebab itu pembicara menjadikan anda sebagai penerima dalam konteks kalimat ini.

Jika dilihat dari sudut pandang uchi (うち) soto ( $と$ ), bendanya jauh dari ruang lingkup pembicara lalu mendekat kepada ruang lingkup pembicara atau orang terdekat dari pembicara, oleh sebab itu menggunakan kata kerja kureru (くれる).

3.あなたは私に何をくれましたか (Anata wa watashi ni nani wo kuremashita $k a$ ) yang berarti "Anda telah memberi apa kepada saya?".

Kata kerja kureru (くれる) dalam bentuk kamus jisho-kei (辞書形) yang diubah kedalam bentuk sopan lampau mashita (ました) menjadi kuremashita (くれました). Ditambah dengan kalimat tanya $k a$ (か) yang berarti kalimat ini adalah sebuah kalimat pertanyaan dalam bentuk lampau. Pembicara, watashi ( 私 ) "saya" dalam kalimat ini mengajukan pertanyaan terhadap lawan bicaranya, anata (あなた) "anda".

Arti dari mashita ka (ましたか) adalah "telah berikan", kalimat ini diucapkan dari sudut pandang pembicara yang ingin mengetahui apa yang telah anda berikan kepada saya dan tentu anata (あなた) disini bukan anggota dari keluarga saya tetapi sangat menghormati anda sebagai lawan bicara, oleh sebab itu si pembicara/watashi 
( 私 ) "saya” menggunakan kalimat pertanyaan dalam bentuk sopan lampau mashita ka (ましたか).

\section{Pola Kalimat Dasar Morau}

Kata kerja morau (もらう) termasuk kedalam kata kerja golongan pertama. Dalam membuat kalimat, jarang sekali hanya menggunakan kalimat morau (もらう) dalam bentuk kamus jisho-kei (辞書形 ), biasanya diperhalus menggunakan bentuk masu-kei (ます形) sebagai rasa hormat pembicara terhadap lawan bicaranya, dan menggunakan bentuk lampau mashita (ました) sebagai kata keterangan bahwa aksi / kegiatan tersebut sudah terjadi. Arti dari kata kerja morau (もらう) adalah menerima, mendapat, diberikan, terima, telah (menyelesaikan) sesuatu, menyuruh (seseorang) melakukan (sesuatu), mendapat keuntungan (dari seseorang yang melakukan sesuatu). Subjeknya biasanya adalah orang pertama atau anggota keluarganya, tapi bisa juga orang kedua dalam pertanyaan. Pola kalimat kata kerja morau (もらう) "menerima" adalah :

は〜に(から)〜をもらう。

A wa B ni (kara) C wo morau:

A menerima $\mathrm{C}$ (objek) dari $\mathrm{B}$.

[Lusiana dkk, 2009]

\section{Analisis Kalimat Morau}

Terdapat enam contoh kalimat yang diteliti dalam penelitian ini. Data penelitian diambil dari berbagai buku yang dipakai di Sekolah Tinggi Bahasa Asing Cipto Hadi Pranoto, yaitu:

1. 僕は彼女(から)ラブレターをもらった (Boku wa kanojo (kara) raburetaa wo moratta) yang artinya "Saya menerima surat cinta (dari) dia".

Kata kerja morau (もらう) dalam bentuk jisho-kei (辞書形) yang diubah kedalam bentuk ta kei (た形) menjadi moratta (もら った) yang artinya "telah menerima" dalam bentuk lampau.
Makna dalam kalimat ini adalah, pembicara yang menjadi orang pertama dalam kalimat ini, menerima sebuah surat cinta dari seorang wanita, yang jelas wanita tersebut bukanlah bagian dari ruang lingkup keluarga si pembicara dari sudut pandang $u$ chi(うち) soto (そと), bendanya jauh dari ruang lingkup pembicara lalu mendekat kepada ruang lingkup pembicara/watashi (私) "saya", oleh sebab itu menggunakan kata kerja morau (もらう).

2.私はあなたに(から)お金をもらいまか (Watashi wa anata ni (kara) okane wo moraimasu ka) yang artinya "Apakah saya akan menerima uang (dari) anda?".

Kata kerja morau (もらう) dalam bentuk jisho-kei (辞書形) yang diubah kedalam bentuk sopan masu kei (ます形) menjadi moraimasu ( もらいま) yang artinya "menerima" dalam bentuk sopan dan ditambah dengan kalimat tanya $k a$ (か) yang berarti kalimat ini adalah sebuah kalimat pertanyaan. Subjek pembicara, watashi (私) "saya", mengajukan pertanyaan terhadap lawan bicaranya anata (あなた) "anda”.

Makna dalam kalimat ini adalah pembicara yaitu watash (私) “saya" ingin mengetahui apakah pembicara akan menerima uang dari lawan bicaranya anata (あなた) "anda". Karena si pembicara menghormati lawan bicaranya yang bukan bagian dari keluarga jadi ia menggunakan kalimat dalam bentuk sopan masu kei (ます形) sebagai tanda hormatnya. Kata kara (から) yang artinya "dari" bisa digunakan, bisa juga tidak digunakan.

3. 私は田中さんから帽子をもらいました (Watashi wa Tanaka san kara boushi wo moraimashita) yang artinya "Saya telah menerima topi dari pak Tanaka".

Kata kerja morau (もらう) yang diubah kedalam bentuk sopan lampau mashita (まし た ) mengalami perubahan menjadi moraimashita (もらいました) yang artinya "telah menerima" suatu kebaikan dari pak Tanaka yang bukan anggota/bagian dari keluarganya si penerima. Penerima sangat menghargai pak Yamada oleh sebab itu penerima/pembicara menggunakan kalimat 
dalam bentuk sopan sebagai rasa hormatnya. Dilihat dari sudut pandang uchi (うち) soto (そと), bendanya jauh dari ruang lingkup pembicara lalu mendekat kepada ruang lingkup pembicara/watashi (私) “saya", oleh sebab itu menggunakan kata kerja morau (も らう).

\section{KESIMPULAN}

Kesimpulan dari penelitian yang dibuat oleh peneliti berdasarkan data-data yang telah peneliti kumpulkan dan menganalisis berlandaskan teori-teori dari para ahli, maka peneliti dapat menyimpulkan hasil dari penelitian ini sebagai berikut:

\section{Makna dari kata ageru (あげる)}

Kata kerja ageru (あげる) artinya adalah “memberi”. Makna kata kerja ageru (あげ る) adalah orang atau subjek yang terlibat dalam kegiatan memberi, yaitu pelaku/pembicara dan orang terdekat dari pembicara, tidak dapat menjadi orang kedua/ketiga atau penerima kebaikan tersebut. Pembicara atau orang terdekat/kerabat pembicara harus menjadi orang pertama/subjek [Makino Michio, 1994].

Berdasarkan perpindahan bendanya dalam konsep soto (そと ) uchi (うち) maka bendanya menjauh/keluar "soto (そ と )" dari ruang lingkup si pembicara/orang pertama sebagai subjek [Mulya Kirana, 2018]. Untuk catatan, kata kerja ageru (あげる) hanya bisa digunakan oleh orang yang derajatnya sama dengan pembicara atau lebih rendah dari pembicara [Maynard, 1997].

\section{Makna dari kata kureru (くれる)}

Kata kerja kureru (くれる) artinya adalah “memberi”. Makna kata kerja kureru $(<れ$ る) adalah memberi dari sudut pandang penerima sebagai pembicara, digunakan untuk menyatakan "pemberian" sesuatu kepada pembicara atau kepada anggota keluarganya yang masih dalam ruang lingkupnya, kalimat ini digunakan dari sudut pandang pembicara sebagai penerima kebaikan [Makino Michio, 1994].

Berdasarkan perpindahan bendanya dalam konsep soto (そと) uchi (うち) maka bendanya mendekat "uchi(うち)" kedalam ruang lingkup si pembicara/orang terdekat si pembicara [Mulya Kirana, 2018].

3. Makna dari kata morau (もらう)

Kata kerja morau (もらう) artinya adalah "menerima". Makna kata kerja morau (も らう) adalah orang pertama/pihak yang menerima suatu kebaikan dari orang kedua/orang ketiga, orang pertama bisa jadi pembicara dari kebaikannya orang lain kepadanya, atau juga kebaikan orang lain kepada orang lain juga [Makino Michio, 1994].

Pada dasarnya, kata kerja morau (もらう) sifatnya adalah umum, siapa saja bisa menggunakannya sebagai ungkapan "menerima" sesuatu dari seseorang [Maynard, 1997].

\section{Penggunaan ageru(あげる)}

Kata kerja ageru (あげる) digunakan pada saat pelaku/pembicara menjadi orang pertama dalam kalimat tersebut dan sebagai yang memberi suatu kebaikan/benda kepada orang kedua atau orang ketiga. Berdasarkan waktu dan kedudukan sosialnya ageru (あげる) dapat mengalami perubahan-perubahan, tergantung cara penggunaannya.

Tabel 5.1 Perubahan kata kerja ageru

\begin{tabular}{|c|c|c|c|}
\hline ggeru(あげる) & 辞書形 & $\begin{array}{c}\text { Bentuk } \\
\text { kamus }\end{array}$ & Memberi \\
\hline agemasu (あげます) & ます形 & $\begin{array}{c}\text { Bentuk } \\
\text { sopan }\end{array}$ & $\begin{array}{c}\text { Akan } \\
\text { memberi }\end{array}$ \\
\hline agemashita (あげました) & た形 & $\begin{array}{c}\text { Bentuk } \\
\text { lampau }\end{array}$ & $\begin{array}{c}\text { Telah } \\
\text { memberi } \\
\text { membah }\end{array}$ \\
\hline
\end{tabular}

\section{Penggunaan kureru (くれる)}

Kata kerja kureru (くれる) kebalikan dari ageru（あげる) digunakan pada saat pelaku/pembicara menjadi orang kedua atau ketiga sebagai penerima suatu kebaikan dari orang pertama. Kata kerja kureru (くれる) digunakan untuk menyatakan "pemberian" sesuatu kepada 
pembicara atau kepada anggota keluarganya yang masih dalam ruang lingkupnya, kalimat ini digunakan dari sudut pandang orang pertama/pembicara sebagai penerima kebaikan. Berdasarkan waktu dan kedudukan sosialnya kureru (< れる) dapat mengalami perubahanperubahan, tergantung cara penggunaannya.

Tabel 5.2 Perubahan kata kerja kureru

\begin{tabular}{|c|c|c|c|}
\hline kureru(くれる) & $\begin{array}{c}\text { 辞書 } \\
\text { 形 }\end{array}$ & $\begin{array}{c}\text { Bentuk } \\
\text { kamus }\end{array}$ & Memberi \\
\hline kuremasu (くれます) & $\begin{array}{c}\text { ます } \\
\text { 形 }\end{array}$ & $\begin{array}{c}\text { Bentuk } \\
\text { sopan }\end{array}$ & Akan memberi \\
\hline kuremashita (くれました) & た形 & $\begin{array}{c}\text { Bentuk } \\
\text { lampau }\end{array}$ & Telah memberi \\
\hline
\end{tabular}

\section{Penggunaan morau (もらう)}

Kata kerja morau ( もらう) digunakan pada saat pembicara menjadi orang pertama/pihak yang menerima suatu kebaikan dari orang kedua/orang ketiga. Berdasarkan waktu dan kedudukan sosialnya morau ( もらう) dapat mengalami perubahan-perubahan, tergantung cara penggunaannya.

Tabel 5.3 Perubahan kata kerja morau

\begin{tabular}{|c|c|c|c|}
\hline $\operatorname{morau}($ もう) & $\begin{array}{c}\text { 辞書 } \\
\text { 形 }\end{array}$ & $\begin{array}{c}\text { Bentuk } \\
\text { kamus }\end{array}$ & Memberi \\
\hline moraemasu (もらいます) & $\begin{array}{c}\text { ます } \\
\text { 形 }\end{array}$ & $\begin{array}{c}\text { Bentuk } \\
\text { sopan }\end{array}$ & $\begin{array}{c}\text { Akan } \\
\text { memberi } \\
\text { sem }\end{array}$ \\
\hline moraemashita (もらいました) & た形 & $\begin{array}{c}\text { Bentuk } \\
\text { lampau }\end{array}$ & $\begin{array}{c}\text { Telah } \\
\text { memberi } \\
\text { memm }\end{array}$ \\
\hline
\end{tabular}

7. Perbedaan kata ageru (あげる), kureru (くれ る), morau (もらう) :

Perbedaan kata kerja ageru(あげる) artinya adalah "memberi" dari sudut pandang orang pertama sebagai pemberi dan tidak bisa menjadi penerima kebaikan. Kata kerja kureru (くれる) artinya adalah "memberi" dari sudut pandang penerima sebagai pembicara. Sedangkan kata kerja morau (もらう) adalah "menerima" dari sudut pandang yang menerima suatu kebaikan, atau pernyataan seseorang kepada orang lain, atas kebaikan yang telah dilakukan oleh orang lain.

\section{DAFTAR PUSTAKA}

Kawashima, S. (1999). A Dictionary of Japanese. Japan: Kodansha International.

Kurniawan, A. (2014). Panduan Lengkap Tata Bahasa Jepang. Yogyakarta: Sketsa.

Lusiana, E., \& dkk. (2009). Buku Pelajaran Bahasa Jepang 3 "Sakura". Jakarta: The Japan Foundation.

Makino, S., \& Michio, T. (1994). A Dictionary of Basic Japanese Grammar. Japan: The Japan Times.

Maynard, S. K. (1997). Japanese Communication: Language and Thought in Context. Honolulu: University of Hawaii Press.

Mulya, M. P., \& Kirana, R. P. (2018). Kesadaran Konsep Uchi-Soto pada Pegawai Thori Co. Ltd. dengan Peserta Magang (EP) dari AIESEC. Japanology, 219-230.

Nirmala, I. (2019). Japanese Profinciency Test N5. Surabaya: Genta Group Production.

Ogawa, i. (2016). Minna no Nihongo I. Surabaya: International Multicultural (I'Mc) Center Press.

Sudjianto, \& Ahmad, D. (2017). Pengantar Linguistik Bahasa Jepang. Jakarta: Kesaint Blanc.

Sugiyono. (2017). Metode Penelitian Kuantitatif Kualitatif. Bandung: CV Alfabeta.

Sutedi, D. (2007). Nihongo no Bunpou. Bandung: Humaniora utama press.

Tomomatsu, E. (2007). Donna Toki Dou Tsukau Nihongo Hyougen Bunkei Jiten. Japan: Alcudia. 